\title{
Underwater observations on copepod swarms in temperate and subtropical waters
}

\author{
H. Ueda ${ }^{1}$, A. Kuwahara ${ }^{2}$, M. Tanaka ${ }^{3}$, and M. Azeta ${ }^{4}$ \\ 1 Department of Marine Sciences, University of the Ryukyus, Nishihara-cho, Okinawa 903-01, Japan \\ 2 Kyoto Institute of Oceanic and Fishery Science, Miyazu-shi, Kyoto 626, Japan \\ 3 Department of Fisheries, Kyoto University, Kyoto-shi 606, Japan \\ 4 Seikai Regional Fisheries Research Laboratory, Nagasaki-shi 850, Japan
}

\begin{abstract}
Swarms of 8 copepod species were visually observed in temperate and subtropical waters along the coast of Japan from 1975 to 1981. Irregular ball-shaped swarms, with diameters less than $1 \mathrm{~m}$, were common for Acartia plumosa, A. erythraea, A. steueri, A. japonica, A. hamata and Oithona oculata. They generally occurred on or a little above the bottom near the shore during the day and maintained their position against slight water currents. A. clausi in Shijiki Bay and O. oculata in Tanabe Bay formed continuous flat swarms and carpeted the bottom with copepods. $A$. steueri in Shijiki Bay, 1978, swarmed within sea grass beds. Labidocera pavo formed small swarms, in which the copepods swirled with each other. Copepod swarms were almost monospecific aggregations except for $A$. erythraea, which was observed to swarm jointly with $A$. plumosa. Within swarms, adult copepods generally dominated and females outnumbered males. For some of Acartia spp., swarms consisted almost entirely of adults, especially females, indicating that the swarming of these species is age- and sex-specific. Adaptive functions of copepod swarms are discussed. Swarming of copepods appears to be a common phenomenon in temperate shallow waters and of significant importance as food resource for some demersal fishes.
\end{abstract}

\section{INTRODUCTION}

Planktonic copepods are usually not randomly distributed even on a small scale (Barnes and Marshall, 1951; Cassie, 1959; Anraku, 1975). Swarms of copepods may be considered an extreme case of nonrandom distribution; the term 'swarm' used here describes an aggregation of animals, much denser than background, resulting from behavior tending to keep the animals in a body of water or to aggregate them in a favorable position. Because it is difficult to detect copepod swarming with usual plankton samplers (e.g. nets, pumps) and to observe small planktonic animals directly, there have been very few studies on copepod swarms.

Using SCUBA diving in coral-reef environments, Emery (1968) observed discrete swarms of the copepods Acartia spinata, A. tonsa, Oithona oculata, and $O$. nana. More recently, Hamner and Carleton (1979) made further observations on copepod swarms on and around coral reefs and recorded aggregations of $A$. australis, $A$. bispinosa, and Centropages orsinii. The latter authors discussed the importance of swarming copepods in coral reef ecosystems and considered that swarming is widespread among tropical copepods.

In waters other than coral reef environments, on the other hand, direct underwater observations on copepod swarms have been rare. Several direct observations were made from ships or from the shore (Russell, 1928; Wada, 1953; Kitou, 1956; Kawamura, 1974; Wiborg, 1976); underwater observation has only been reported by Bainbridge (1952). Swarming behavior of copepods in mid- and bottom-waters other than the tropics has remained almost unknown.

We made underwater observations in temperate and subtropical locations along the coast of Japan from 1975 to 1981 and found copepod swarms of 8 species. Herein, we provide information on their swarming behavior, as well as on the composition and density of their swarms.

\section{MATERIALS AND METHODS}

Underwater observations were made by skin diving and, if necessary, with SCUBA at 6 locations around southern Japan (Fig. 1). Of these locations, Sesoko 


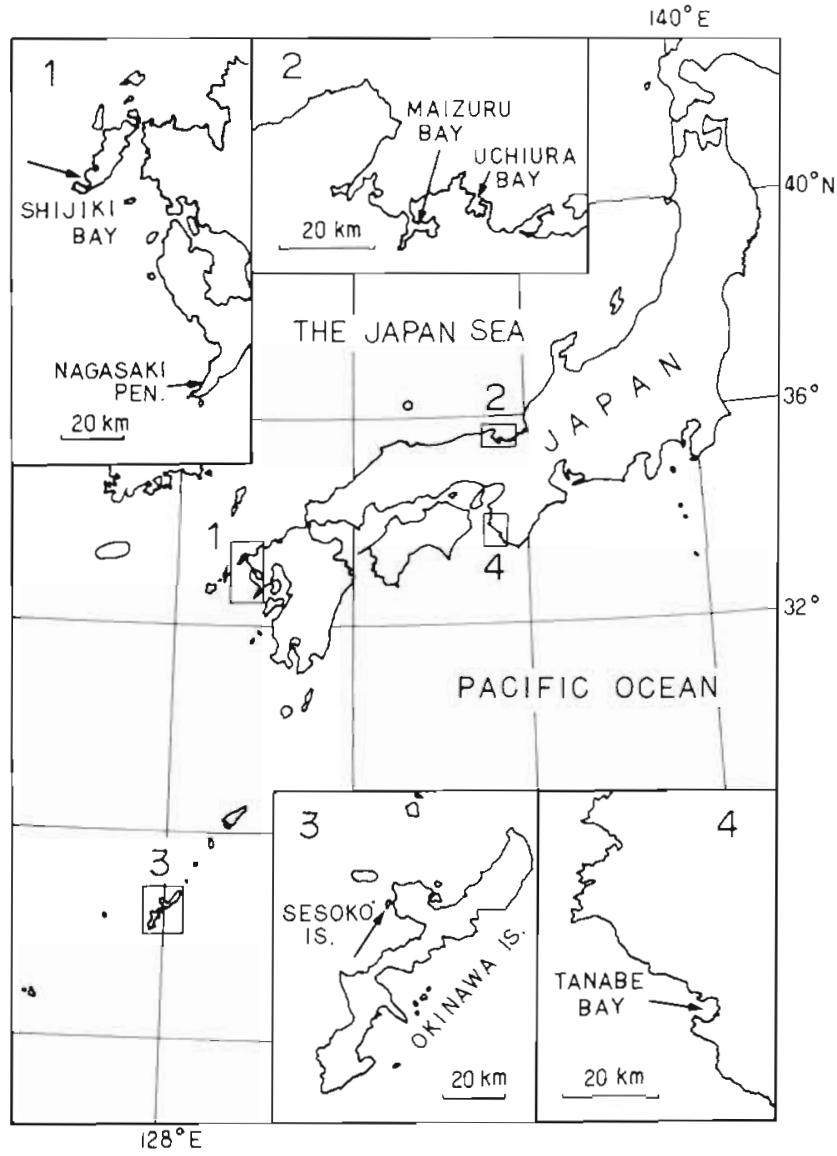

Fig. 1. Location of observation sites. Insets: Details with geographic names mentioned in text

Island is a subtropical region, the others are temperate ones. Dates and swarming species observed are listed in Table 1. Copepods within swarms were generally collected with diver-operated conical nets $(10 \mathrm{~cm}$ mouth diam., $30 \mathrm{~cm}$ long with $0.1 \mathrm{~mm}$ mesh cloth), the mouth being covered between samples with a removable cap to prevent contamination by background copepods before and after collection. A large net with
$30 \mathrm{~cm}$ mouth diam. was used to sample 1 swarm of Acartia plumosa to determine the internal density of the swarm. For quantitative samplings of $A$. steueri in Shijiki Bay (1978) we made a sampler of our own construction, consisting of 2 acrylic resin tubes $(25 \mathrm{~cm}$ long, $4 \mathrm{~cm}$ in diam.) fixed at one end of a $1 \mathrm{~m}$ long shaft. The mouths of the tubes were designed to be closed with plastic caps and the trigger was set at the opposite end of the shaft so that a diver could collect copepods at least $1 \mathrm{~m}$ away without disturbing them. Copepods within swarms of Oithona oculata in Tanabe Bay and of A. steveri and A. clausi in Shijiki Bay (1980) were sampled by diving with Van Dorn water samplers. For comparison with internal compositions of swarms, background copepods were collected for $A$. steueri in Tanabe Bay and A. japonica in Uchiura Bay by diving with hand nets. O. oculata in Tanabe Bay was also collected from background water at various depths by diving with a Van Dorn water sampler.

To observe diurnal changes of swarming behavior of Acartia plumosa in Maizuru Bay, we made underwater observations 6 times from $1500 \mathrm{~h}$ of 2 August to $1400 \mathrm{~h}$ of 3 August, 1975; the observation at night was made with help of an underwater flashlight. Size and number of the swarms along a $10 \mathrm{~m}$ white measuring tape, placed on the bottom about $0.5 \mathrm{~m}$ deep, were recorded at each observation time. Night observations were also made of $A$. steueri in Shijiki Bay (1978). Nocturnal vertical distribution of Oithona oculata in Tanabe Bay was obtained with a Van Dorn water sampler from a boat.

For most of the copepods studied, samples were divided according to developmental stage and sex. In the samples from Tanabe Bay (1976) and Shijiki Bay (1980), the closely related Acartia stueri and A. clausi occurred together. The copepodids from $\mathrm{CII}$ to $\mathrm{CV}$ were distinguished with rostrum filaments, which are present in $A$. steueri and absent in $A$. clausi, but the number of $\mathrm{CI}$ was not separately counted due to difficulty of identification. A. japonica from Uchiura Bay

Table 1. Underwater observations: localities, dates and species of swarming copepods

\begin{tabular}{|c|c|c|}
\hline Locality & Date & Swarming copepods \\
\hline Maizuru Bay & $\begin{array}{l}22 \text { Jul. }-1 \text { Sep. } 1975^{\circ} \\
8 \text { Sep. } 1975\end{array}$ & $\begin{array}{l}\text { Acartia plumosa, Labidocera pavo } \\
\text { Acartia erythraea }\end{array}$ \\
\hline Tanabe Bay & $\begin{array}{l}16-17 \text { Apr. } 1976 \\
1 \text { Aug. } 1978\end{array}$ & $\begin{array}{l}\text { Acartia steueri } \\
\text { Oithona oculata }\end{array}$ \\
\hline Uchiura Bay & 10. Aug -13 Sep. $1978^{\circ}$ & Acartia japonica \\
\hline Shijiki Bay & $\begin{array}{l}15-16 \text { Jul. } 1978 \\
18 \text { Jun. } 1980\end{array}$ & $\begin{array}{l}\text { Acartia steueri } \\
\text { Acartia steueri, A. clausi }\end{array}$ \\
\hline Nagasaki Peninsula & 16, 20 Sep. 1978 & Oithona oculata \\
\hline Sesoko Island & $\begin{array}{l}10 \text { Jul. } 1979 \\
27 \text { May } 1981\end{array}$ & $\begin{array}{l}\text { Acartia hamata } \\
\text { Oithona oculata }\end{array}$ \\
\hline
\end{tabular}


was hard to distinguish from co-occurring $A$. erythraea, but for this pair of species, we could distinguish the species of copepodids CIII to CV by spines on the first segment of the antennule, absent in $A$. japonica and present in $A$. erythraea. But these spines were not developed in CI and CII, and these stages were not counted separately

\section{RESULTS}

\section{Field observations}

Although the shape of copepod swarms depended on the species and the localities, the most common type was irregular ball-shaped (Table 2). Each ball-shaped swarm was most often spherical or ovoid, but sometimes became stretched out longitudinally. These swarms were fairly distinct with clear boundaries. Their diameters ranged from a few centimeters to over $1 \mathrm{~m}$, but most swarms were smaller than $50 \mathrm{~cm}$ in diameter. They usually stayed at the same position and contacted the bottom or were a little above it. Copepods within a swarm were hopping up and sinking down against the slight water current with their heads diagonally downward. These swarms were easily broken by the turbulence caused by a diver and also by escape reactions of the individuals when a diver closely approached them.

In Maizuru Bay, Acartia plumosa swarms were commonly observed over the sandy or gravelly bottom of nearshore water on sunny and calm days throughout the summer. Frequently the swarms were located on the bottom in water less than $2 \mathrm{~m}$ deep around the shore and were not found deeper than $10 \mathrm{~m}$. They generally occurred on the bottom without raising off the substrate; a spherical swarm ( $30 \mathrm{~cm}$ in diam.) in midwater was seen only once (28 August) about $0.5 \mathrm{~m}$ off the bottom in water $1 \mathrm{~m}$ deep. A. plumosa often swarmed over some white object, such as broken pieces of white ceramic wares, glittering cans, and so on. Such swarms, especially on glittering white objects reflecting the sunlight, were generally well developed and elongated along the shaft of the reflected sunlight. They occasionally extended up to the sea surface and formed columns of copepods in the shallow water. The swarms during the summer of 1975 were monospecific aggregations of $A$. plumosa but, on 8 September 1978 , we observed $A$. plumosa and a large species, $A$. erythraed, swarming jointly. These mixed-species swarms were also formed over white objects on the shallow bottom.

Ball-shaped swarms of Acartia steueri occurred on the slope of the rocky shore near the mouth of Tanabe Bay. These copepods also swarmed along the edges of the rocks bounding the sandy flat bottom at about $10 \mathrm{~m}$ depth, but never on sandy bottom away from the rocks. In Shijiki Bay, 1980, a similar type of A. steueri swarms occurred on the sandy flat bottom about $14 \mathrm{~m}$ deep with sparse sea grass Zostera marina. But there were no swarms over the grassless sandy bottom nearby

In the innermost part of Uchiura Bay, there is a shallow (less than $2 \mathrm{~m}$ deep) embayment containing algal beds of Sargassum tortile. We observed ballshaped swarms of Acartia japonica above or immediately adjacent to the algal beds. However, the copepods did not form any swarms within the thickets of the algae and in water apart from the algal beds. The swarms usually hovered about 5 to $10 \mathrm{~cm}$ above the substrate. We observed swarms at this site until early

Table 2. Swarming data: species, locality, swarm shape and size, depth, and position of swarms

\begin{tabular}{|c|c|c|c|}
\hline Species (locality*) & Shape and diameter of swarm & Depth $(\mathrm{m})$ & Swarming position \\
\hline Acartia plumosa (M. B.) & Irregular balls, $5 \mathrm{~cm}-1 \mathrm{~m}$ & $0.3-10$ & $\begin{array}{l}\text { Over sandy or gravelly bottom, } \\
\text { especially on white objects }\end{array}$ \\
\hline A. erythraea ' (M. B.) & Irregular balls, $10-30 \mathrm{~cm}$ & $0.5-1.5$ & Over white objects \\
\hline A. steveri (T. B.) & Irregular balls, $10-50 \mathrm{~cm}$ & $3-10$ & Over rocky shore \\
\hline A. steveri (S. B., 1978) & N. D. & $3-5$ & Throughout entire sea grass beds \\
\hline A. steueri (S. B., 1980) & Irregular balls, $30-60 \mathrm{~cm}$ & 14 & Over sandy flat bottom \\
\hline A. japonica (U. B.) & Irregular balls, $10-50 \mathrm{~cm}$ & $0.5-2$ & Above algal beds \\
\hline A. hamata (S. I.) & Ovoid, $20 \mathrm{~cm}$ & 0.5 & Over sandy bottom among coral reefs \\
\hline A. clausi (S. B.) & Continuous flat swarm, N. D. & 14 & Over sandy flat bottom \\
\hline Labidocera pavo (M. B.) & Disc-shaped swarms, $10-20 \mathrm{~cm}$ & $0.5-1$ & Above bottom around algal belts \\
\hline Oithona oculata (T.B.) & Continuous flat swarm, N. D. & $6-14$ & Over sandy flat bottom \\
\hline O. oculata (N.P.) & Irregular balls, $10 \mathrm{~cm}-1.5 \mathrm{~m}$ & $1-10$ & Above rocky shore with algal beds \\
\hline O. oculata (S. I.) & Irregular balls, $10 \mathrm{~cm}-3 \mathrm{~m}$ & $0.5-3$ & Above algal patches in reef area \\
\hline
\end{tabular}


in September, but not after the beginning of the stormy season in mid-September.

We found only 1 swarm of Acartia hamata in a fringing coral reef area along the southwest coast of Sesoko Island. This swarm was ovoid (ca. $20 \mathrm{~cm}$ in diam., $30 \mathrm{~cm}$ high) and remained on the bottom at about $0.5 \mathrm{~m}$ depth, about $1 \mathrm{~m}$ away from the nearest coral colony. In the summers of 1980 and 1981, we reexamined the same site but could not find any copepod swarms

Ball-shaped swarms of Oithona oculata occurred in the nearshore water of the northwest coast of Nagasaki Peninsula. This site is directly connected to the open sea and featured beds of Sargassum sp. or Eisenia sp. where the shore was rocky. We commonly observed the swarms in small clearings within the algal beds. They also occurred in the transitional zone from the rocky shore to the sandy bottom about $10 \mathrm{~m}$ deep, and often in open rocky pockets, in which the swarms usually were deformed longitudinally, occasionally exceeding $1 \mathrm{~m}$ in the long axis. Swarms were absent from the sandy flat-bottom area without shelter but occurred rarely in depressions of the bottom containing algal debris and beside rocks or boulders isolated but not far from the rocky shore. The swarms generally maintained a distance from the bottom of 5 to $10 \mathrm{~cm}$. Similar swarms of $O$. oculata occurred in the coral reef area of Sesoko Island, where the copepods generally swarmed on or a few centimeters above patches of the brown alga Chnoospora implexa on the reef flat and along the reef margin. Swarms that formed over algae patches on declivities of the reef margin were generally well developed, sometimes exceeding several meters in diameter.

Acartia clausi in Shijiki Bay and Oithona oculata in Tanabe Bay formed continuous flat swarms over the bottom layers so that they carpeted the bottom. Copepod density within these swarms varied from one place to another but so gradually that copepods never formed discrete ball-shaped swarms with clear boundaries. The aggregations of copepods, even in dense parts of the swarms, were looser than the ball-shaped swarms described above. A continuous swarm of $A$. clausi was observed near the site where the ballshaped swarms of $A$. steueri occurred. However, swarming of the former appeared more clearly in the grassless area, in contrast with the latter which swarmed only in association with the sea grass. The swarm of $A$. clausi was about $30 \mathrm{~cm}$ thick and kept a distance of about $5 \mathrm{~cm}$ above the bottom. A continuous, flat swarm of $O$. oculata occurred over the sandy flat bottom deeper than 6 to $7 \mathrm{~m}$ at the mouth of the bay, and not over bottom shallower than $6 \mathrm{~m}$, where waves generated relatively strong water movement at the time we made underwater observations. This swarm, varying in thickness from 5 to $30 \mathrm{~cm}$, was closely associated with the bottom and its upper boundary was clearly observed when viewed from the side.

In the innermost part of Shijiki Bay, 1978, Acartia steueri formed dense aggregations within beds of Zostera marina. These aggregations were patchily distributed on the sandy bottom 3 to $5 \mathrm{~m}$ deep. Within a patch of sea grass, copepods swarmed among grass shoots from the bottom to the tops of the grass blades (about $30 \mathrm{~cm} \mathrm{high)} \mathrm{and} \mathrm{from} \mathrm{end} \mathrm{to} \mathrm{end} \mathrm{of} \mathrm{the} \mathrm{patch}$ without observable density variation. Although copepods aggregated even in a small assemblages of grass shoots, they were rarely found in the water outside the sea grass patches. Swarming copepods showed no active movements, except hopping up and sinking down, unless a diver disturbed them.

Swarms of Labidocera pavo occurred 5 to $10 \mathrm{~cm}$ above the bottom around belts of Sargassum spp., partiy lining the shore in Maizuru Bay. They generally consisted of only several tens of copepods, which swirled quickly and smoothly with each other in a swarm about 10 to $20 \mathrm{~cm}$ in diameter. The aggregation of copepods, therefore, was much looser than in the swarms of the other species described above, but the swarming of $L$. pavo was more easily distinguished because of the dark blue coloration of the copepods. When a diver closely approached a swarm, it dispersed at once and quickly reassembled in another position.

In Maizuru Bay Acartia plumosa swarms occurred throughout the daytime, although they were fewer at dusk or dawn than at high noon (Table 3). At night, copepods did not form any swarms but were fairly evenly distributed throughout the water column. In Shijiki Bay A. steueri also dispersed at night. In this case, copepods were more abundantly observed in surface water than in grass beds or the bottom layer at night. At dawn, copepods began to aggregate in the grass beds but their density was still much lower than at high noon.

Table 3. Acartia plumosa. Diumal changes in the number of swarms along a $10 \mathrm{~m}$ white measuring tape in Maizuru Bay, 1975. L, $M$ and $S$ : large (>ca. $30 \mathrm{~cm}$ in diam.), medium ( $\mathrm{ca}$ $10-30 \mathrm{~cm}$ ) and small (<ca. $10 \mathrm{crn})$ swarms, respectively

\begin{tabular}{|c|c|c|c|c|c|}
\hline \multirow[b]{2}{*}{ Date } & \multirow[b]{2}{*}{ Time } & \multicolumn{4}{|c|}{ No. of swarms } \\
\hline & & $\mathrm{L}$ & M & $S$ & Total \\
\hline \multirow[t]{3}{*}{2 Aug. } & 1500 & 1 & 4 & 7 & 12 \\
\hline & $1900^{\circ}$ & 0 & 2 & 1 & 3 \\
\hline & 2340 & 0 & 0 & 0 & 0 \\
\hline \multirow[t]{3}{*}{3 Aug. } & $0515^{\cdots}$ & 0 & 2 & 1 & 3 \\
\hline & 1030 & 7 & 8 & 4 & 19 \\
\hline & 1400 & 4 & 12 & 3 & 19 \\
\hline \multicolumn{6}{|c|}{ - Sunset; 1903} \\
\hline \multicolumn{6}{|c|}{ - Sunrise; 0507} \\
\hline
\end{tabular}




\section{Composition and density of swarms}

The samples obtained from swarms generally contained very small numbers of planktonic or epibenthic copepods other than members of the swarming species. Copepod nauplii, including those of the swarming species, were also scarce in swarm samples. Copepod swarms were generally monospecific aggregations, except for the mixed-species swarms of Acartia plumosa and $A$. erythraea in Maizuru Bay; in 3 samples obtained from these mixed-species swarms the ratios of $A$. plumosa to $A$. erythraea varied from $1: 0.8$ to $1: 3.3$.

Composition data of Acartia spp. and Oithona oculata swarms are presented in Table 4. Since some early copepodid stages were neglected in 4 observations in which separation of co-occurring species was difficult, in these 4 cases adult percentages are somewhat too high. On the other hand, the numbers of young copepods were much smaller than those of older individuals so that the values presented are considered not to differ very much from the real situation. Adult copepods generally constituted the major part of the swarms. Especially, swarming copepods of A. plumosa, $A$. erythraea, A. japonica and A. steueri (Shijiki Bay, 1978) consisted almost entirely of adults. Adults constituted less than $50 \%$ of the copepods within swarms of A. steueri from Tanabe Bay and $O$. oculata from Tanabe Bay and Nagasaki Peninsula. Adults, however, were more abundant than any copepodid stage, and $\mathrm{CV}$ to $\mathrm{Cl}$ were progressively less abundant with decreasing age.

Among adults, females generally outnumbered males in the swarms of all species studied, and Acartia swarms consisting almost entirely of adults showed extreme values of adult sex ratios. The percentage of adults and the adult sex ratio within $A$. plumosa swarms varied somewhat depending on sampling dates. For example, 83.8 to $93.4 \%$ of the copepods were adults and 80.0 to $93.4 \%$ of the adults were females in samples obtained on 22 July; these values gradually increased up to 97.8 to $99.9 \%$ and 98.1 to $99.7 \%$, respectively, on 28 August.

The proportion of adults to juveniles in Acartia spp. sampled from background waters differed significantly from that within swarms. In samples obtained by random sweeping with a hand net above the sandy bottom in Tanabe Bay, swarming $A$. steueri were less abundant than $A$. clausi. A steueri which were all immature and mostly younger than CIII. In Uchiura Bay we collected a background sample from water above algal beds where $A$. japonica swarms occurred. In this sample, the percentage of adult $A$. japonica, obtained by omitting CI and CII, was apparently lower $(43.1 \%$ ) than that within the swarms.

A sample from an Acartia plumosa swarm contained 8190 individuals. The swarm was almost spherical and about $20 \mathrm{~cm}$ in diameter. Supposing all A. plumosa of this swarm had been collected, the volume of the $20 \mathrm{~cm}$ sphere $\left(=0.004 \mathrm{~m}^{3}\right)$ was comparised of 8190 copepods. Extrapolating to $1 \mathrm{~m}^{3}$, total swarm density was $2 \times 10^{6}$ $\mathrm{m}^{-3}$. In $A$. steueri collected within sea grass beds in Shijiki Bay (1978), with a sampler of our own construction, swarming density varied from $7 \times 10^{4}$ to $5 \times 10^{5}$ $\mathrm{m}^{-3}$ among 8 samples, even though it appeared by direct observation that the copepods were fairly evenly distributed over the entire sea grass beds. This variability was probably caused by grass blades that clogged the mouths of our sampling tubes. Therefore, our present estimates for this species are considered to be lower than the real swarming density. Quantitative samplings by Van Dorn water samplers gave swarm densities of $3 \times 10^{5} \mathrm{~m}^{-3}$ for $A$. clausi in Shijiki Bay,

Table 4. Percentages of adults and females fractions in Acartia spp. and Oithona oculata swarms sampled from 1975 to 1978

\begin{tabular}{|c|c|c|c|}
\hline Species (locality ${ }^{\bullet}$ ) & $\begin{array}{l}\text { No. of samples } \\
\text { examined }\end{array}$ & $\begin{array}{c}\text { Mean \% of adults } \\
\text { (range) }\end{array}$ & $\begin{array}{c}\text { Mean } \% \text { of females among } \\
\text { adults (range) }\end{array}$ \\
\hline A. plumosa (M. B.) & 12 & $95.1(83.8-99.9)$ & $93.6(80.0-99.7)$ \\
\hline A. erythraea (M. В.) & 3 & $93.5(85.7-98.3)$ & $92.9(89.2-95.8)$ \\
\hline A. steueri (T. B.) & 1 & $43.1 \cdots(-)$ & $55.9(-)$ \\
\hline A. steueri (S. B., 1978) & 8 & $99.2(97.5-100.0)$ & $91.2(83.3-100.0)$ \\
\hline A. steueri (S. B., 1980) & 1 & $50.0^{\cdots} \cdot(-)$ & $37.0(-)$ \\
\hline A. japonica (U. B.) & 5 & $96.2(79.4-98.6)^{\cdots} \cdots$ & $97.4(97.0-99.0)$ \\
\hline A. hamata (S. I.) & 1 & $73.1(-)$ & $83.1(-)$ \\
\hline A. clausi (S. B.) & 1 & $52.6^{\cdots}(-)$ & $72.4(-)$ \\
\hline O. oculata (T. B.) & 3 & $37.6(35.6-41.7)$ & $61.5(58.2-67.0)$ \\
\hline O. oculata (N. P.) & 2 & $36.8(32 . \dot{0}-41.6)$ & $57.3(52.8-61.7)$ \\
\hline O. oculata (S. I.) & 2 & $78.0(68.0-88.0)$ & $71.5(60.0-82.9)$ \\
\hline \multicolumn{4}{|c|}{$\begin{array}{l}\text { - See Table } 2 \\
\cdots \text { Obtained by omitting CI } \\
\cdots \text { Obtained by omitting } \mathrm{CI}\end{array}$} \\
\hline
\end{tabular}


and of $4 \times 10^{5} \mathrm{~m}^{-3}$ for Oithona oculata in Tanabe Bay. The density of ball-shaped swarms of $A$. steueri in Shijiki Bay could not be estimated successfully because the tube of the sampler used was too long $(45 \mathrm{~cm})$ for accurate sampling inside a swarm.

In Tanabe Bay background densities of Oithona oculata at various depths $(0,2,4,6.5,7 \mathrm{~m}$; the latter being $0.5 \mathrm{~m}$ above bottom) were all less than $1.0 \times 10^{3}$ $\mathrm{m}^{-3}$. In contrast, densities determined at various depths (from surface to bottom) at night were more than $2.0 \times 10^{3} \mathrm{~m}^{-3}$ (Table 5). This indicates that the

Table 5. Oithona oculata. Densities of adults and copepodids at various depths at night in Tanabe Bay, 1978

\begin{tabular}{|cc|}
\hline Depth $(\mathrm{m})$ & Density $\left(\times 10^{3} \mathrm{~m}^{-3}\right)$ \\
\hline 0 & 2.0 \\
2 & 9.0 \\
4 & 9.7 \\
6 & 13.0 \\
6.5 & 9.2 \\
7 (bottom) & 8.0 \\
\hline
\end{tabular}

swarm dispersed throughout the water column at night. Instar and sex compositions of copepods sampled at night were similar to those swarming during the day.

We collected 61 individuals of Labidocera pavo from a swarm of this species in Maizuru Bay. Most copepods were CIV and CV (25 and 26, respectively); there were only 2 females and 6 males.

\section{DISCUSSION}

As observed by Hamner and Carleton (1979) for copepod swarms on coral reefs, high adult percentages appear to be a general feature of Acartia spp. and Oithona oculata swarms in temperate waters. In contrast, according to vertical hauls of a plankton net in Shijiki Bay (Ueda, 1980), A. clausi younger than CIV were much more abundant than older stages during the reproductive season. In Maizuru Bay, where $A$. plumosa swarms occurred, one of us (H. U., unpubl.) found that adults generally comprised only a few percent of the A. plumosa population in samples obtained by vertical hauls of a net throughout the reproductive season. In the present study, adult copepods were fewer than juveniles in background waters for $A$. steueri in Tanabe Bay and for A. japonica in Uchiura Bay. This indicates that Acartia spp. swarms are not only species-specific but also age-specific. Furthermore, swarming of these Acartia species appears to be more or less sex-specific, because the high occurrence of adults was related to the large number of fernales in the swarms.
Hamner and Carleton (1979) list several adaptive functions associated with copepod swarming: protection from predators, facilitating a chance for mating, keeping position to feed on coral mucus, and restricting dispersion by currents. They suggested that protection was of major importance among these functions and that a combination of advantages was operative in populations developing seasonally in reef lagoons. In the copepod swarms observed by us, important functions may vary depending on the types of swarming. Facilitation of mating appears to be equally important as protection in ball-shaped swarms of Acartia spp. which consist mainly of adults. Swarming of adults may strengthen the effect of sex pheromones (Katona, 1973), even though the swarms consisted mainly of females. The major adaptive function of continuous flat swarms over the bottom - observed for A. clausi in Shijiki Bay and for Oithona oculata in Tanabe Bay may differ from that of ball-shaped ones: the former swarm type seems to represent aggregations due to extensive vertical migration.

Among the functions pointed out by previous authors, reduction of dispersion by currents appears to be important for the swarms studied here as well. The swarms occurred on, or a little above, the bottom; or in sheltered spaces where water currents were generally weak. Maintaining their position against the currents, the swarms would permit these neritic copepods, especially adult females producing offsprings, to stay in their preferred habitats.

Copepod swarming is considered to be a common phenomenon in temperate shallow waters, as well as in tropical reef environments, since the swarming Acartia clausi, A. plumosa, A. steueri and Oithona oculata are common in neritic waters around Japan (Ueda, 1982). Anraku (1975) suggested that aggregations of copepods are convenient as food for plankton feeders such as fish larvae and juveniles with less advanced abilities of swimming and food searching. Even in food-scarce environments, they would be able to feed on a large amount of food when encountering aggregations. Tanaka and Ueda (unpubl.) analyzed stomach contents of juvenile red sea bream Pagrus major in Shijiki Bay and found that some stomachs contained immature $A$. clausi and $A$. steueri together with isopods, but that others were almost filled with adult $A$. steueri. This observation suggests that the juveniles fed on $A$. steueri swarms consisting mainly of adult copepods, and that copepod swarms are of importance as food during early demersal life for some coastal fishes.

Acknowledgements. We are indebted to Drs. M. Anraku, M Omori, and W. M. Hamner for their critical reading of the manuscript and valuable suggestions. Observations and 
samplings in Shijiki Bay were made as a part of the study on the ecology of the red sea bream, which was conducted by the Seikai Regional Fisheries Research Laboratory, and we express our gratitude to our colleagues for their kind support. We also thank Mr. T. Nishikawa for assistance in the samplings in Tanabe Bay, 1978. Special thanks are also due to Dr. C. C. Davis for his revising of the manuscript.

\section{LITERATURE CITED}

Anraku, M. (1975). Microdistribution of marine copepods in a small inlet. Mar. Biol. 30: 79-87

Bainbridge, R. (1952). Underwater observations on the swimming of marine zooplankton. J. mar. biol. Ass. UK. 31: $107-112$

Barnes, H., Marshall, S. M. (1951). On the variability of replicate plankton samples and some applications of 'contageous' series to the statistical distribution of catches over restricted periods. J. mar. biol. Ass. UK. 30: 223-263

Cassie, R. M. (1959). An experimental study of factors inducing aggregation in marine plankton. N.Z. Jl Sci. 2: 339-365

Emery, A. R. (1968). Preliminary observations on coral reef plankton. Limnol. Oceanogr 13: 293-303

Hamner, W. M., Carleton, J. H. (1979). Copepod swarms: attributes and role in coral reef ecosystems. Limnol. Oceanogr. 24: 1-14

Kawamura, A. (1974). Food and feeding ecology in the southern sei whale. Scient. Rep. Whales Res. Inst. 26: 25-144

Katona, S. K. (1973). Evidence for sex pheromones in planktonic copepods. Limnol. Oceanogr 18: 574-583

Kitou, M. (1956). Shoals of Calanus helgolandicus (Claus) (in Japan.). Inf. Bull. Plankton Soc. Japan 3: 41

Russell, F. S. (1928). The vertical distribution of marine macroplankton. VII. Observation on the behaviour of calanus finmarchicus. J. mar. biol. Ass. UK. 15: 429-454

Ueda, H. (1980). Zooplankton investigations in Shijiki Bay. I. Compositions of zooplankton and distribution of copepods from April to August, 1975. (in Japan; Engl. abstract.) Bull. Seikai Reg. Fish. Lab. 54: 171-194

Ueda, H. (1982). Zooplankton investigations in Shijiki Bay. II. Zooplankton communities from September 1975 to April 1976, with special reference to distributional characteristics of inlet copepods. (in Jap.; Engl. abstract.) Bull Seikai Reg. Fish. Lab. 58: 1-23

Wada, S. K. (1953). Notes on the ecology of a plankton copepod, Labidocera pavo Giesbrecht. Rec. oceanogr. Wks Japan 1: 100-102

Wiborg, K. F. (1976). Fishery and commercial exploitation of Calanus finmarchicus in Norway. J. Cons. int. Explor. Mer 36: $251-258$

This paper was presented by Professor M. Anraku; it was accepted for printing on November 24, 1982 